\title{
The Ethno-National Identity of Estonian and Russian Youth in Respect of their Primordialist or Situationalist Orientations
}

\author{
Tarmo Tuisk \\ Department of International Relations, \\ Tallinn University of Technology \\ Akadeemia tee 3 , \\ Tallinn 12618, Estonia \\ E-mail: tarmo.tuisk@tseba.ttu.ee
}

Abstract: Estonia has been often regarded as a country of contrasts. This contrast-based societal constellation appears to be surprisingly well accepted by the majority of the population-both Estonians and Russians living in Estonia. A sudden freedom of expression and behaviours provided new opportunities for differentiation within and between the ethnic groups led to new cleavages between winners and losers, the successful and the unfortunate.

Identity Structure Analysis (ISA) as a theoretical framework was applied to investigate identity construal processes within these two largest ethnic groups in Estonia. ISA is a complex theoretical framework, building on several psychological theories, taking into consideration developmental factors, social psychological and cognitive processes. Ethnic identity is understood as an expression of continuity between one's construal of past ancestry and one's future aspirations in relation to ethnicity.

A distinction is made between a 'primordialist'and a 'situationalist' understanding of ethnic identity: Primordialists define ethnicity interms of ancestry, whereas situationalists perceive ethnicity as being socially constructed, taking into consideration fluidity and change.

ISA permits an empirical investigation of these construal processes of ethnic identity across the primordialist-situationalist spectrum. These often unconsciously held convictions are thought to contribute to the cleavages within the contemporary Estonian society. In addition, issues such as the command of the Estonian language, citizenship, the influence of the Second World War on European history, out-group acceptance, tolerance, globalisation, social responsibility, the role of government and the current economic crisis are also considered to be some of the essential features in constructing identities. 
An ISA study was carried out among Estonian and Russian university students, the resultant data was analysed using Ipseus software.

Keywords: Estonia, ethnic and national identity, identity construction, identity structure analysis, primordialism, Russians in Estonia, situationalism

\section{Introduction}

The restoration of Estonian nation-state has been "the most visionary futuredirected project of the Estonian people" (Ruutsoo, 2002, p. 52). Throughout the last two decades the search for a common national identity that has been considered as a basis uniting all ethno-demographic groups in Estonia, has proved an extremely challenging task for the entire society. Despite several elaborated and implemented integration programmes and policies, the integration of the society has not been completed, and efforts to achieve this will be continued.

The current study aims to make a contribution to this topic. The identities of Estonians and Russians living in Estonia are analysed using a developmental and socio-psychological approach for investigating the fundamental features of Estonian and Russian identity structures through in-depth assessment of underlying identity processes. Identity Structure Analysis (Weinreich, 1986[1980]; Weinreich \& Saunderson, 2003), facilitated by Ipseus software (Weinreich \& Ewart, 2007), provides the conceptual and methodological tools for assessing cleavages in identity orientations of the two largest ethnic groups in Estonia. These orientations are underpinned by primordialist sentiments on the one hand and situationalist perspectives on the other. Furthermore, the extent to which there exist features that contribute to a common Estonian national identity across cleavages both between and within Estonian conceptions and Estonian-Russian conceptions will also be established.

Although Identity Structure Analysis (ISA) has been used several times in Estonia since 1993 (Kirch \& Laitin, 1994; Rimm \& Tuisk, 1997; Kirch, Rull \& Tuisk, 2001; Kirch \& Tuisk, 2005; 2008; Kirch, Tuisk \& Reinkort, 2011), the concepts and theory related to primordialism and situationalism have never been considered by researchers within these studies in Estonia. ISA has been successfully used to assess and investigate ethnic identity in several countries (e.g., Horenczyk \& Munayer, 2003; Weinreich, Luk \& Bond, 1996; Kelly, 1989). ISA studies in relation to primordialist and situationalist paradigm have been carried out in Northern Ireland and Slovakia (Weinreich, Bacova \& Rougier, 
2003). The approach allows an in-depth assessment of the contribution of psychological processes to issues of ethno-national identity, thereby augmenting sociological and political science analyses.

\section{Theoretical basis}

\subsection{Aims of the current study}

ISA is an open-ended framework of theoretical concepts and postulates about the processes of identity development and redefinition (Weinreich, 2003, p. 1). Within the current article, the ISA metatheoretical framework has been applied to study ethnicity and ethnic identity. Due to continued existence of ethnic conflicts all over the world, the concept of ethnic identity has been elaborated by many researchers. There exist two stances of ethnic identity-some researchers have demonstrated that the origins of a person's ethnic identity are ascribed at birth and remain unchanged for the entire life while others claim that ethnic identity has to be constructed and reconstructed during one's lifespan.

The distinction between these two types of ethnicities and ethnic identities has been clearly delineated (Glazer \& Moynihan, 1975, as cited in Weinreich, Bacova \& Rougier, 2003, p. 115). "The one that emphasizes the issue of ethnic persistence - a seemingly unchanging aspect of ethnicity, which persists down the generations, is called primordialism (Shils, 1957; Geertz, 1963; Greely, 1974; Isaacs, 1975; Connor, 1978; Smith, 1981; Weinreich, Bacova \& Rougier, 2003, p. 115) and the other that highlights the situational features of ethnic revivalism is called situationalism" (Hechter, 1974; Mitchell, 1974; Nagata, 1974; Epstein, 1978; Halsey, 1978; Okamura, 1981; Weinreich, Bacova \& Rougier, 2003, p. 115). Application of ISA has enabled researchers to show the developmental primacy of primordialism, that is despite people's basic propensity for primordialism, there exist also persons who develop the situationalist perspective during their lifespan while questioning their status quo in the changing world (Weinreich, Bacova \& Rougier, 2003).

The aim of the current study is to investigate whether the Estonians and Russians living in Estonia differ in terms of these orientations. A better understanding of identity construal processes and belief systems, which may not be conscious to the individuals concerned, is required in order to contribute to a better societal integration of Estonia. For this purpose I have carried out an ISA study among Estonian and Russian students, and the resultant data have been analysed using Ipseus software. 


\subsection{Definitions: primordialism and situationalism}

When studying ethno-national identity, it is essential to show the context of how primordialism and situationalism as the main concepts of the study in relation to ethnic and national identity have been revised and defined within the new theoretical approach by Weinreich and his colleagues. According to them, simply acknowledging the two discernible perspectives on nationality and ethnicity is not sufficient. Primordialism has been taken within this analysis as 'the basic and initial lay perspective' on nationality or ethnicity as representing the cohesiveness of 'peoplehood'. It is an emotive 'gut feeling' sense of affinity with the people in question (Weinreich, Bacova \& Rougier, 2003, p. 118).

Primordialism is defined as a sentiment, or affect laden set of beliefs and discourses, about a perceived essential continuity from group ancestry to progeny (perceived kith and kin), located symbolically in a specific territory or place (which may or may not be the current place of the people concerned) (Weinreich, Bacova \& Rougier, 1997; 2003, p. 119; Weinreich, 1998)

The set of beliefs and discourses forming primordialist sentiments is not predetermined. It may vary from person to person and from culture to culture, but certainly these beliefs and discourses will express the perceived essential ancestral continuity - in terms of language, tradition and custom; the inevitability of the ethnicity or nationality; the necessary relationship to the land, etc. Upon reflection about what has been initially taken as a natural order of things, some people will develop more of a situationalist perspective (Weinreich, Bacova \& Rougier, 2003, p. 118). To them, nations have not been considered as eternally stable entities - on the contrary - they are rather being constructed and reconstructed throughout history.

Situationalism is defined as a set of beliefs or discourses about the instrumental and socially constructed nature of the group, in which interpretations and reinterpretations of history provide rationales justifying the legitimacy of a peoplehood. (Weinreich, Bacova \& Rougier, 1997; Weinreich, 1998)

The definitions presented above are not exclusive. A person can simultaneously hold beliefs and values that refer to aspects of both primordialism and situationalism, thereby people who hold wholly one or another type of these beliefs consistently are considered to be rare. 


\section{Background of the study}

Since Estonia regained its independence in 1991 a need to resolve practical issues about how to make the 'restored nation-state' (in a form of liberal democracy) and its ethno-demographic realities of the post-colonial environment correspond. A discursive conflict between human rights and imperatives of the nation-state was already implanted into the nation-building project. The ethnic consolidation perspective of a nation-state was reshaped to the discourse of modernisation, which launched the project of building liberal community, incorporating collective rights for minorities. At the same time language requirements for obtaining national citizenship were not regarded as a tool for communitarian nation building, but as a precondition for active republican citizenship (Ruutsoo, 2002, pp. 52-53). At the end of the 1990s when the threat to the Estonian language and culture was no longer perceived to be as direct as before, the government adopted the 'Estonian Integration Programme 2000-2007'. While the main idea of the programme was to promote a multicultural society where all cultures are treated as equal, this overall principle appeared to be in contradiction with the aim of the Estonian statehood (Vetik, 2002, p. 60). Despite the fact that the state had to create conditions for the cultural development of ethnic minorities, it has been preordained at the constitutional level that Estonia should stay and will remain Estonia-centred as the aim of Estonian statehood itself is the preservation of the totality of the Estonian language and cultural space (State Programme, 2000, p. 23).

The Estonian social scientist Marju Lauristin (2011, p. 194) gives a broader view when analysing reasons of societal developments in regard to inclusion and exclusion during the last 20 years after the country regained its independence. According to her, it is paradoxical in Estonia that despite social troubles, people continuously support liberal economic policies and are ready to express support for a rightwing government that makes drastic cuts. Her analysis is commensurate with Henri Vogt who has adopted the concept of 'nation-liberalism' which values statehood as an institution that supports economic success, which is used to legitimise the readiness to make social sacrifices (for example, to unquestioningly support crisis cutbacks, which painfully affect families with children, the social security of workers, as well as schools and cultural institutions) as "national virtues". Commenting on the results of Estonia's last elections which kept the coalition that made the drastic cuts in power, Vogt writes:

What these results seem to tell, above all, is that the political and economic course that Estonia has followed over the past two decades 
is now widely accepted by the citizenry.[...] the Estonian political system, its polity, continuously obtains its basic energy from a strong sense of being a national Gemeinschaft, a community of ethnic Estonians. (Vogt, 2011, p. 40)

This is an appeal to a 'primordialist' sentiment of a national community of ethnic Estonians, which must pose some difficulty for Russian primordialists, whose identity is Russian (living in Estonia), compared with Russian situationalists, whose identity is Russian-Estonian. Here it becomes evident that the 'culture' of Estonia, despite the political rhetoric about cultural pluralism, is thereby predominantly primordialist.

Vogt continues:

This also means that a large part, or perhaps the majority, of the country's citizens have deemed the sacrifices of the past 20 years necessary and above all justified. Many ordinary Estonians, far more than was expected as the new era of independence dawned, have suffered severely during the post-Soviet transformation processes. The cleavages between winners and losers, between the successful and the unfortunate, have often been deep and clear-cut; [...] The deepest cleavage of all is, of course, that between the Russianspeaking population and the native Estonians. (Vogt, 2011, p. 40)

According to Vogt's construction of Estonian society, Estonians and Russians are expected to show the sharpest distinction according to delineation along ethnic lines. It is expected to be true in most of the cases. At the same time researchers have found the Russian-speaking community very heterogeneous (Laitin, 1998; Vihalemm \& Kalmus, 2009) in their attitudes, depending on how native they are to Estonia, their citizenship status, age, education, social position and Estonian language skills, to point out some factors. In response to Estonians' overall primordialism, exposed through 'nation-liberalism', a guess is that these tough societal changes have established grounds for Russians' primordialism as well. Still, the heterogeneity of Russians at large is reflected in non-Estonians' increasing overall polarisation within integration processes. Estonian Integration Monitoring 2011 (2012, p. 7) shows that during 20082011 the degree of integrated residents of other ethnicities has not changed (remaining at 61\%), while the share of strongly integrated residents and of those who have not integrated at all, has increased. The latter category can be related first of all to primordialists, and those who have been able to integrate more successfully will have a stronger propensity towards situationalism. 


\section{Earlier studies in Estonia}

Ethnic and national identity of Estonians and Russians has been studied by Martin Ehala, who approaches Estonia's Russians and their identity changes by dividing the Russians' identity development in independent Estonia into developmental periods (Ehala, 2008). During the second half of the 1990s, the attitudes of Estonians and Russian speakers towards integration were more positive than at any other time since the restoration of independence. Estonians' and Russians' ideals coincided during the 2000-2004 period which can be labelled as a period of integration and consumer individualism, based largely on economic growth. Despite all positive effects of joining the EU in 2004, it was accompanied by new threats like invasion of the English language, possible arrivals of new immigrants, a weakening of the sense of national pride, and emigration. In the years 2004-2007, the weakening of ethnic identities emerged as a salient issue in radical nationalist circles and ways were actively sought to mobilise the nationalist sentiment. This feeling of threat is a major reason for the creation of conflicts between two subgroups of the same category. According to Ehala, in such situations ethnic conflict is the most effective way to sharpen the definition of boundaries between groups. The development of events was greatly influenced by Russia's new identity policy. Russia's celebration of the $60^{\text {th }}$ anniversary of the end of the Second World War clearly showed that victory in the "Great Patriotic War" is one of the most important sources of national pride for Russian identity (Ehala, 2008). This finding is also consistent with the Bronze Soldier crisis of 2007. The removal of the Bronze Soldier, a Second World War memorial which was erected by the Soviet power in 1947, from the centre of Tallinn to a military cemetery, was followed by riots. Most of the Russian protesters partaking in the riots were youth who could speak the Estonian language. These riots signalled that for ethnic Russians, language learning is not sufficient for creating a common national identity or feelings of belonging to Estonia. Thereby within the current study language policies and their influence to Estonians' and Russians' identity construction will be one of the main foci. 


\section{Formulation of the research question and the hypotheses}

Earlier studies have shown that since the beginning of the collapse of the Soviet Union, first the ethnic identity of Estonia's Russians became privatised and threatened, thereafter influences of globalisation and consumerism weakened both Estonian and Russian ethnic identities, although a starting point for the construction of a shared national identity was almost within reach. Instead, these gaps on either side became fulfilled with nationalism. As far as both Russians and Estonians were concerned, the stronger linkage to the Soviet past became visible and started to dominate again (Ehala, 2008). Parallel societies of Estonians and Russians, which have existed since the Soviet times and were mostly supported by two parallel educational systems, were separated through two different languages of instruction (Lindemann \& Saar, 2011, pp. 61-63). Determined efforts to change the educational system towards being monolingual through governmental policies became an issue of high salience among Russians as these policies were perceived as a measure for forced assimilation accompanied with limited possibilities for education in their mother tongue. Negative outcomes of integration could possibly be a source of retrenchment towards basic primordialism among both ethnic groups in Estonia, as both Estonians' and Russians' ethnic identities could be perceived as being threatened.

The current study aims to elucidate the underlying socio-psychological processes that result in primordialist sentiments among both ethnic groups in their ethnic identity structure construction. It also aims to specify areas that are the most distinctive and others that are the most shared among the Estonian and Russian ethnic identities in order to sort out possible common starting points for the formation of a shared national identity in the future.

In the following, I will review three postulates (Weinreich, Bacova \& Rougier, 2003), and taking into account Estonia's local interethnic environment (i.e. the distinction between ethnic Estonians and Russians), I will formulate four hypotheses to facilitate the analysis of locally gathered data.

The first postulate concerns the influence of variations in the development of nationhood.

Postulate 1: Diversified socio-cultural ethos, individual cosmopolitanism and situationalism

Those historical cultural and personal circumstances that stimulate people to think of the complexities of nationhood-acknowledging 
fluidity and diversity — will generate a greater propensity towards situationalism. (Weinreich, Bacova \& Rougier, 2003, p. 122)

Weinreich et al. have explained and justified this postulate through the example of Protestant British in Ulster who should by way of their historical experience of the British national debate about diverse cultural heritages express situationalism, while Catholics in Ireland should be more prone through unquestioning Irish Catholicism to primordialist perspectives (Weinreich, Bacova \& Rougier, 2003, p. 123). Within the framework of my study concerning Estonians and Russians in Estonia, both ethnic groups have experienced (and suffered) a lot during the changes occurring over the last 20 years. Still, the guess is that for Estonians, who have enjoyed independence and own statehood, joined the European Union and NATO, introduced their own currency in 1992 and the euro in 2011, the post-Soviet change has been more stable and positive compared to Russians, whose status from a prestigious majority of the Soviet Union to a minority in a small independent state, separated by the state border from their historical homeland, forced them to follow integration policies adopted in Estonia to protect Estonians and "their" nation-state. The worst blows for Russians (in all ex-Soviet republics) were the adoption of the language law(s) in 1989 and the collapse of the USSR itself, called 'the double cataclysm' by David Laitin (1998, p. 85). The expectation here would be that:

Hypothesis 1a: Given the historical change from the former Soviet domination to their current status within Estonia, those Russians who hold contemporary allegiance to Estonia are more likely to be situationalists than Estonians who experience the longstanding continuity over generations of Estonian heritage (that is, Estonians will remain more primordial).

Hypothesis 1b: Other Russians in Estonia who do not hold contemporary allegiance to Estonia are more likely to be primordialists (identifying more closely with Russians of Russia).

\section{Postulate 2: Situationalists' enhanced developmental change in identity}

Given their developing questioning stance on 'nationality', situationalists compared with primordialists will show a greater perceived change in the ethnic or national aspect of their identities over time and greater modulation in their empathetic identifications with others who represent primordialist or situationalist perspectives on 'nationality'(Weinreich, Bacova \& Rougier, 2003, p. 125). 
As already formulated in Hypotheses $1 \mathrm{a}$ and $1 \mathrm{~b}$, whereby the flexibility and developments of identity concerning time perspective should be more evident among Russians, the expectation here will be given in the following hypothesis.

Hypothesis 2: Due to their experience of more profound societal change for them, a heightened developmental change will be the most distinctive among Russian situationalists' identity accompanied also by their greater modulation with 'political groupings' and ethno-national winners/losers groups. Thereafter, Estonian situationalists should demonstrate the second highest developmental modulation.

\section{Postulate 3: Consonant discourses as core evaluative dimensions of identity}

For the more strident primordialists, ISA postulates that they will endorse and express primordialist discourses as core evaluative dimensions of identity with high structural pressures when appraising national or ethnic agencies in their social world. Likewise, for the more ideologically committed situationalists, ISA postulates that they will use situationalist discourses with high structural pressures (Weinreich, Bacova \& Rougier, 2003, p. 150).

Postulate 3 will be used to define the following in order to underline the role of consonant discourses in regard to primordialism and situationalism among Estonians and Russians, the following hypothesis was formulated.

Hypothesis 3: Primordialists will endorse and express primordialist discourses as core evaluative dimensions of identity with high structural pressures when appraising national or ethnic agencies in their social world. Likewise, situationalists will use situationalist discourses with high structural pressures.

\section{Research method}

\subsection{Defining identity parameters}

The following identity parameters of ISA will be used in the analysis.

Empathetic identification with another:

The extent of one's current empathetic identification with another is defined as the degree of similarity between the qualities one attributes 
to the other, whether 'good' or 'bad', and those of one's current selfimage (Weinreich, [1980]1986; Weinreich, 2003).

Emotional significance:

The emotional significance of a construct used by one during appraisal of one's social world is defined as the strength of affect associated with the expression of the construct (Ewart \& Weinreich, 2006).

Structural pressure on a construct:

The phrase 'structural pressure on a construct' is introduced to refer to the pressures that arise from the structures of cognitiveaffective consonances and dissonances associated with the use of the construct:

The structural pressure on a person's construct is defined as the overall strength of the excess of compatibilities over incompatibilities between the evaluative connotations of attributions one makes to each entity by way of the one construct and one's overall evaluation of each entity (Weinreich, [1980]1986; 2003).

\subsection{Study design and respondent selection}

The ISA identity instrument used in this study was custom-designed for this research and was based on my best understanding of ethnic and cultural features central to Estonians and Russians living in Estonia and to the major research questions addressed in the introduction to this article. The entities and constructs were selected on the basis of previous studies carried out in Estonia among Estonians and Russians and also on a comparative in-depth study of primordialism and ethnic identity in Northern Ireland and Slovakia (Weinreich, Bacova \& Rougier, 2003).

\subsubsection{Formulation of constructs}

Although in 2011 the world was slowly recovering from the economic crisis that started already in 2008 , there is still a need to include a construct which would assess a population's ability and prospects to relate this expected recovery from the crisis with the 'right-wing government that makes drastic cuts' (Lauristin, 2011, p. 194). The construct was phrased as follows: 
1L ...believe/s that despite policies of large cuts implemented thus far, only the current government is capable of steering Estonia out of the economic crisis

1R ...believe/s that success in recovering from the crisis does not depend on the particular government that Estonia has today

The people of the Baltic States have viewed their countries' economic peril as a personal challenge and have expressed a collective desire to protect their countries from the devastating impact of the global crisis. References have also been made to the earlier experiences of the Baltic countries, especially Estonia, as they coped with the post-Communist economic collapse in the early 1990s by implementing radical economic reforms (Lauristin, 2011, p. 193). Possible collectively committed devotion here should be tested with the following bipolar construct:

2L ..feel/s that the difficulties that Estonia's society has gone through and the experience of the transition shock have helped the society to manage the current crisis

2R ...feel/s that managing the current crisis does not depend on the experience of having survived the post-Soviet transition period and difficulties

While linguistic-communicative integration, which means the reproduction of a common information space, has been considered one of the key aspects for successful societal integration, there has to be a certain common understanding among the population groups indicating that Estonian language and culture have a future. Also, will the command of Estonian language easily guarantee outgroup acceptance for Russians? Two following constructs were included:

3L ...know/s that the Estonian language and culture are based on history and traditions, and have a future

3R ...believe/s that Estonian culture and language are destined to vanish in the globalising world

4L ...believe/s that it is easy for Russians to merge into the Estonian society by knowing the Estonian language

$4 \mathbf{R}$ ...believe/s that it is difficult for Russians to merge into the Estonian society even with a full command of the Estonian language 
The idea of the following construct is to use respondents' assessment of the presence of ethnic cleavage in the society.

5L ...think/s that there are no grounds to claim that there are ethnic cleavages in the Estonian society

5R ...think/s that there exists a deep cleavage in the Estonian society

The following constructs were included to help respondents to evaluate self and others from the aspect of civic values.

6L are/is tolerant towards other people and views

6R do/es not accept other people and different views

9L ...have/has a good sense of ethics and social responsibility

9R ... are/is prone to corruption and self-aggrandisement

Scientific evidence is still lacking on whether increasing the severity of penalties for those who do not comply with language laws is the best way to regulate language use. On the contrary, there are indications that the opposite is true- - thick and control-orientated policies aimed at unifying complex language practices that are not in conformity with the official language ideology tend to work very slowly (Vihalemm \& Siiner, 2011, p. 123). Although stronger control has not been considered an effective measure in Estonia, the following construct was included to let the respondents evaluate the effectiveness of language policies in general while the attitudes of respondents and their significant others concerning the overall repulsion to control was tested.

7L ...believe/s that by strengthening control and penalties when implementing language policy accelerates linguistic integration and use of the official language

$7 \mathbf{R}$

...believe/s that strong control and penalties do not result in faster integration and greater use of the official language

Despite the fact that ethnic affiliation has been considered less important than language proficiency in differentiating opportunities for participation in the labour market or public life, the claim that wealthier non-Estonians have easier access to language and citizenship because of their socio-economic position (Lauristin, 2011, p. 196) is included as a bipolar construct in order to view the role of such inequality in the construction of both Russian and Estonian respondents' identity. 
8L $\quad . . . t h i n k / s$ that the wealthier and more successful non-Estonians have gained, along with a better socio-economical position, both language skills and citizenship

8R

...think/s that non-Estonians'command of the Estonian language and citizenship does not relate to their socio-economical position

The ideologisation of cultural space, especially when it has been done through thesis and antithesis, delineated by the interpretation of the history of the Second World War, stifles open discussion in the society. In order to evaluate the seriousness of this claim within one's identity structure, the following construct was included:

10L ...is/are of the opinion that the Soviet Union was first of all the liberator of Eastern Europe in the Second World War

10R ...is/are of the opinion that the Soviet Union was first of all the occupier of Eastern Europe in the Second World War

In order to let a Russian respondent construe his or her affiliation with Estonia and to measure Estonian respondents' acceptation of Estonia's Russians, the following construct was included:

11L ...believe/s that Russians living in Estonia have more in common with Estonia being their country of residence

11R ...believe/s that Estonian Russians feel more in common with Russia being the country of their origin

The following three constructs were used to determine the respondents' belongingness either to the primordialist or situationalist category. Constructs 12, 13 and 14 were elaborated by Peter Weinreich and his colleagues for the comparative study of primordialism and were effectively used in Northern Ireland and Slovakia (Weinreich, Bacova \& Rougier, 2003, p. 133). (P) and (S) indicate primordialist or situationalist polarity in the case of each construct, respectively.

12L ...believe/s that national ties override divisions of wealth and social position $(P)$

12R ...believe/s that economic interests rather than national ones unite a people (S)

13L $\quad$...consider/s nationality is given forever $(P)$

13R $\quad$... a person is able to adapt to being of any nationality (S) 
14L ...believe/s that a common ancestral language is the essential hallmark of national and ethnic heritage $(P)$

$\mathbf{1 4} \mathbf{R} \quad .$. believe/s that a common ancestral language is not necessary for national belonging (S)

\subsubsection{Selection of entities}

The entities which were used for the research were divided into five domains. According to the ISA methodology there are four mandatory entities within the domain of self (current self, ideal self, contra-ideal self and past self). The domain of personal heritage involves respondent's parents, while his/her friends belong to the domain of significant persons. The domain of national/ ethnic groups includes both ethnic groups divided into 'winners' and 'losers' to enable the respondent to evaluate the categories which include successful or unsuccessful role model related to each ethnic group during his or her assessment. Here the dimension of 'winners' and 'losers' will be a cognitive category for the respondents to identify with, although in earlier studies in Estonia these categories have been operationalised (e.g., Narusk \& Hansson, 1999). 'Russians in Russia' is included as an optional external other to identify or contra-identify with. In order to measure respondents' affiliation with political groupings, entities like 'government today' and the 'opposition in Riigikogu' (the Parliament of Estonia) were also included.

\subsubsection{Study instrument and respondent selection}

The ISA instrument was administered to two groups of students. The idea was to investigate the identity of Estonians and Russians by using the postulates to be verified instead of testing the hypotheses described above. The instrument was prepared consisting of 14 entities and 14 constructs. The instrument employed in the study was printed in Estonian and in Russian and was identical in both languages. The bipolar construct appeared at the top of each page, below which were listed 14 entities, each followed by a nine-point scale. The bi-directional centre-zero rating scales (4-3-2-1-0-1-2-3-4) made no a priori assumptions of favourable or unfavourable connotations associated with either end of the scale. The idea was to have as homogeneous sample as possible in order to eliminate variations caused by age, social position and highest educational level gained. I had to use student sample, as the resources to carry out a more extensive fieldwork were limited.

All students were majoring in international relations at the Tallinn University of Technology. The question about ethnicity was included as background 
information. Only students who reported their ethnicity being 'Estonian' or 'Russian' were selected for the analysis. The year of birth of all of the students ranged from 1989 to 1992.

\section{Results}

In order to be able to distinguish between primordialists and situationalists among Estonians and Russians, both ethnic groups were divided before analysis according to their ideal self-positioning in regard to the following construct:

13L $\quad$...consider/s nationality is given forever $(P)$

13R ... a person is able to adapt to being of any nationality (S)

The final distribution of respondents by ethnicity, gender and primordialist/ situationalist division is presented in Table 1.

Table 1. Division of respondents into primordialists and situationalists

\begin{tabular}{|l|r|l|l|l|l|r|}
\hline & \multicolumn{2}{|l|}{ Estonians $\mathrm{n}=23$} & \multicolumn{2}{l|}{ Russians $\mathrm{n}=22$} & \\
\hline & Primordialists & $\begin{array}{l}\text { Situatio- } \\
\text { nalists }\end{array}$ & Primordialists & $\begin{array}{l}\text { Situatio- } \\
\text { nalists }\end{array}$ & Total \\
\hline Male & 4 & 6 & 4 & 8 & 22 \\
\hline Female & 7 & 6 & 6 & 4 & 23 \\
\hline Total & 11 & 12 & 10 & 12 & 45 \\
\hline
\end{tabular}

The analysis by Ipseus software was carried out for four groups of respondents:

- Estonian primordialists $(\mathrm{n}=11)$; overall these 11 cases are distinctly primordialist (Table 4, see p. 148).

- Estonian situationalists $(\mathrm{n}=12)$; overall these 12 cases are very weakly situationalist with obtruding primordialist sentiment (Table 5, see p. 149).

- Russian primordialists $(\mathrm{n}=10)$; overall these 10 cases are strongly primordialist (Table 6, see p. 150).

- Russian situationalists ( $\mathrm{n}=12)$; overall these 12 cases are weakly or conflicted situationalist (Table 7, see p. 151).

The division of the research participants into primordialists and situationalists was compromised by the lack of individuals expressing strong situationalist perspectives on ethnicity and nationality - the 'situationalists' of the investigation 
are only weakly so (as these cases are far from holding a clear-cut situationalist perspective, they will be referenced hereafter in quotation marks to indicate this). If these findings were representative of the Estonian population, they would indicate generally primordialist Estonian and Russian cultures in Estonia, somewhat more so among the Estonians than the Russians. Further research with representative samples would be required to establish the generality of the respective ethno-national cultural propensities. The fieldwork data, after being entered and transferred into electronic format for analysis, were processed using Ipseus software. Four hypotheses (reformulated from the postulates) were tested using identity parameters generated from computer analysis. Interpretation of these results is as follows.

Hypothesis 1a: Given the historical change from former Soviet domination to their current status within Estonia, those Russians who hold contemporary allegiance to Estonia are more likely to be situationalists than Estonians who experience the longstanding continuity over generations of Estonian heritage (that is, Estonians will remain more primordial).

Hypothesis 2b: Other Russians in Estonia who do not hold contemporary allegiance to Estonia are more likely to be primordialists (identifying more closely with Russians of Russia).

Table 2. Empathetic identification of respondents with ethno-national groups

\begin{tabular}{|l|r|r|r|r|r|r|}
\hline & \multicolumn{4}{|l|}{ Estonians } & \multicolumn{4}{l|}{ Russians } \\
\hline & PRIM & \multicolumn{1}{l|}{ SIT } & F-ratio & PRIM & SIT & F-ratio \\
\hline $\begin{array}{l}\text { Estonia's Russians - } \\
\text { winners }\end{array}$ & 0.58 & 0.63 & 0.276 & 0.66 & 0.63 & 0.169 \\
\hline $\begin{array}{l}\text { Estonia's Russians - } \\
\text { losers }\end{array}$ & 0.32 & 0.35 & 0.387 & 0.68 & 0.51 & $5.401^{* *}$ \\
\hline Estonians - winners & 0.85 & 0.73 & $4.175^{\star}$ & 0.44 & 0.52 & 1.311 \\
\hline Estonians - losers & 0.65 & 0.61 & 0.225 & 0.53 & 0.46 & 0.969 \\
\hline Russians in Russia & 0.34 & 0.28 & 0.765 & 0.59 & 0.46 & $3.211^{*}$ \\
\hline
\end{tabular}

${ }^{*} p<=0.1 ;{ }^{* *} p<=0.05$; Scale range: Identification 0.00 to 1.00 .

PRIM: Primordialists; SIT: Situationalists

This evidence suggests that the ethos of Estonians is predominantly primordialist as indicated by the 'Estonians - winners', with whom PRIM Estonians identify more closely and empathetically (0.85) than SIT Estonians (0.73). Compared to 'situationalists', primordialist Russians identify more closely and empathetically 
with those Russians who do not 'fit in' Estonia ('Estonia's Russians - losers') (0.68 cf. 0.51$)$ and 'Russians in Russia' (0.59 cf. 0.46). The closest empathetic identification that any of these groupings has is 0.85 for primordialist Estonians with 'Estonians - winners', followed by 0.73 for 'situationalist' Estonians with Estonian winners, then by 0.68 for primordialist Russians with 'Estonia's Russians - losers', and then by only a moderate 0.63 for 'situationalist' Russians with 'Estonia's Russian - winners' (Table 2).

These results show that hypothesis 1a was valid since 'flexible' and Estonianminded Russian 'situationalists' identified with 'Estonia's Russians - winners' that shows their allegiance towards Estonia while both Estonian primordialists and 'situationalists' through their high identifications (with Estonians winners) demonstrated overall primordialism among Estonians. Hypothesis $1 \mathrm{~b}$ was also valid as 'Russians in Russia' was most highly supported by Russian primordialists, which demonstrates their identification with roots and the importance of historical legacy within their identity construction.

Hypothesis 2: Due to their experience of more profound societal change for them, a heightened developmental change will be the most distinctive among Russian situationalists' identity accompanied also by their greater modulation with 'political groupings' and ethno-national winners-losers groups. Thereafter, Estonian situationalists should demonstrate the second highest developmental modulation.

The evidence about ongoing processes stated in Hypothesis 2 is presented in Table 3. Estonian 'situationalists' demonstrate a four per cent greater average change when compared to primordialists $(9.4 \% \mathrm{cf} .13 .4 \%)$. This means that in regard to Estonians the hypothesis is valid. In addition, when examining carefully, 'situationalists' show the biggest changes in increasing identification with 'Estonia's Russians - winners' (+19\%) and two most decreasing identifications are with 'Estonia's Russians - losers' (-23\%) and 'Russians in Russia' (-36\%). Here Estonian 'situationalists' report their "addiction to success" while ethnicity as identification category seems to be of secondary importance. 'Estonia's Russians - winners' have been taken as possible 'business partners' becoming like 'in-group members' to identify with. At the same time tremendous distancing from 'Russians in Russia' marks a deepening distancing from Russians as the "others". Even Estonian primordialists do not distance in identification to such an extent from 'Russians in Russia' (-18\%), instead their identification with their own ethno-national group ('Estonians - winners') has increased almost by $15 \%$ during the last four years. The overall estimation about Estonian 'situationalists' is their numerically greater modulation in identifications when focusing on three key 
identification patterns concerning Russians. Estonian primordialists have moved closer to their Estonian core, namely 'Estonians - winners', and changing less in their attitudes about Russians in general (as when compared to 'situationalists').

When comparing the mean differences of Russian primordialists and 'situationalists' ( $8.5 \%$ cf. $26.4 \%)$ the summarised averaged changes in modulation of empathetic identity are substantially more visible, and changes in the identification of 'situationalists' are more evident compared to that of primordialists as expected by the hypothesis. The primordialists' identification with both the government and the opposition has decreased while the identification of 'situationalists' has increased with both, especially with the government (39\%). In regard to their own group, 'situationalists' again show noticeable identification change with their 'winners' (18\%) while there is no change among primordialists at all. Instead, primordialists have started to identify more strongly with 'losers' $(+5 \%)$ while the "situationalists" degree of similarity with them has decreased by 16 per cent. The positive change in the identification of 'situationalists' with both Estonian 'winners' and 'losers' (39-41\%) corresponds to the decrease in identification with both Estonians' groups among Russian primordialists. The inflexibility of primordialists in any direction is also exemplified with unchanged identification with 'Russians in Russia' while the identification of 'situationalists' with the latter category has dropped by 24 per cent.

As the analysis of the data in Table 3 shows, Russian primordialists express in their identification changes 'frozen' attitudes even in regard to identifying with their own winners' group.

They are also the only of the four analysed groups here whose almost all identification developments are neutral or negative with only one exception among the seven agents or agencies - a slight "positive" change $(5 \%)$ towards 'Russians - losers'. At the same time, the most "positive" group are Russian 'situationalists' whose two decreasing identifications are only with 'Estonia's Russians - losers' and 'Russians in Russia'. At first glance it is possible to conclude that their "pro-Estonia speed rate" has been much higher than among Estonians themselves. Another and even more wide-reaching conclusion is that the cleavage among Russian primordialists and Russian 'situationalists' is noticeably larger than the cleavage between Estonians and Russians in general. Also, the cleavage between Estonian primordialists and 'situationalists' remains less significant, although 'situationalists' are closer to Russians in their identifications. These results clearly demonstrate that, while there are clear-cut Russian primordialists and 'situationalists', the Estonian 'situationalists' are not clear-cut, but retain elements of primordialist sentiment. 
The Ethno-National Identity of Estonian and Russian Youth in Respect of their Primordialist or Situationalist Orientations

Table 3. Empathetic identification based on the past and current self-images with 'political groupings' and national winners-losers groups

\begin{tabular}{|c|c|c|c|c|c|c|c|c|c|c|c|c|}
\hline & \multicolumn{6}{|c|}{ Estonians } & \multicolumn{6}{|c|}{ Russians } \\
\hline & \multicolumn{3}{|c|}{ Primordialists } & \multicolumn{3}{|c|}{ 'Situationalists' } & \multicolumn{3}{|c|}{ Primordialists } & \multicolumn{3}{|c|}{ 'Situationalists' } \\
\hline & Past & Current & \%diff & Past & Current & $\%$ diff & Past & Current & $\%$ diff & Past & Current & $\%$ diff \\
\hline $\begin{array}{l}\text { Government } \\
\text { of Estonia } \\
\text { today }\end{array}$ & 0.72 & 0.71 & -1.4 & 0.62 & 0.64 & +3.2 & 0.46 & 0.40 & -15.0 & 0.36 & 0.50 & +38.9 \\
\hline $\begin{array}{l}\text { Opposition in } \\
\text { Riigikogu }\end{array}$ & 0.60 & 0.60 & 0.0 & 0.54 & 0.57 & +5.6 & 0.56 & 0.50 & -12.0 & 0.50 & 0.58 & +9.4 \\
\hline $\begin{array}{l}\text { Estonia's } \\
\text { Russians - } \\
\text { winners }\end{array}$ & 0.55 & 0.58 & +5.4 & 0.53 & 0.63 & +18.9 & 0.66 & 0.66 & 0.0 & 0.54 & 0.63 & +16.7 \\
\hline $\begin{array}{l}\text { Estonia's } \\
\text { Russians - } \\
\text { losers }\end{array}$ & 0.38 & 0.32 & -18.7 & 0.43 & 0.35 & -22.9 & 0.65 & 0.68 & +4.6 & 0.59 & 0.51 & -15.7 \\
\hline $\begin{array}{l}\text { Estonians } \\
\text {-winners }\end{array}$ & 0.74 & 0.85 & +14.9 & 0.69 & 0.73 & +5.8 & 0.52 & 0.44 & -18.2 & 0.37 & 0.52 & +40.5 \\
\hline $\begin{array}{l}\text { Estonians } \\
\text {-losers }\end{array}$ & 0.70 & 0.65 & -7.7 & 0.62 & 0.61 & -1.6 & 0.58 & 0.53 & -9.4 & 0.33 & 0.46 & +39.4 \\
\hline $\begin{array}{l}\text { Russians in } \\
\text { Russia }\end{array}$ & 0.40 & 0.34 & -17.6 & 0.38 & 0.28 & -35.7 & 0.59 & 0.59 & 0.0 & 0.57 & 0.46 & -23.9 \\
\hline Mean \% diff & & & 9.4 & & & 13.4 & & & 8.5 & & & 26.4 \\
\hline
\end{tabular}

Scale range: Identification 0.00 to 1.00 .

Hypothesis 3: Primordialists will endorse and express primordialist discourses as core evaluative dimensions of identity with high structural pressures when assessing national or ethnic agencies in their social world. Likewise, situationalists will use situationalist discourses with high structural pressures.

In order to test this hypothesis, the following comparison of the values and beliefs of eleven Estonian primordialists (moderately strongly so) and twelve weak 'situationalists' (retaining primordialist sentiments) will be reviewed (see Tables $4 \& 5$ ). Identity parameters (emotional significance and structural pressure) reported by the Ipseus analysis have been provided in the Tables where the first three constructs as indicative in regard to propensities towards classification as 'primordialists' or 'situationalists' have been grouped at the top, thereafter all other constructs have been analysed in order to distinguish between these two orientations. 
The twelve Estonian 'situationalists' have an overall weak situationalist perspective on ethno-nationality and retain distinctly primordialist sentiments, which suggests that in practice there is only a marginal differentiation between their ethno-national orientation and that of the eleven Estonian primordialists. Marginal differences are revealed in a slight tendency for the 'situationalists' towards individual autonomy, contrasted with the primordialists' tendency towards the status quo of the current government and socio-economic status, so that 'situationalists' tend to endorse the belief (conflicted) that recovering from the current crisis does not depend on the part of the Estonian government, whereas primordialists tend to believe (conflicted) that only the government can lead Estonia out of the economic crisis; and non-Estonians' command of the Estonian language and citizenship does not relate to their socioeconomical position, while primordialists tend to endorse the belief (conflicted) that wealthier and more successful non-Estonians have gained, along with a better socio-economical position, both language skills and citizenship. These findings suggest that Estonian culture at large (as represented by these Estonian participants) is predominantly primordialist, with only a very weak element of situationalist perspective restricted to only a few Estonians (cf. Weinreich, Bacova \& Rougier, 2003).

Further differences between the 'situationalists' and the primordialists are revealed in the structural pressures on endorsements of the beliefs that Estonian society is not ethnically cleavaged (this is substantially greater for 'situationalists' at 52.19 compared with 33.32 for primordialists) and the expression of tolerance towards other people and views (substantially greater for 'situationalists' at 69.85 compared with 59.04 for primordialists).

In other respects, as assessed by the discourses included in the instrument, there are minimal differences to be found. The core concerns as common prominent dimensions of the Estonian participants' identity are that the Estonian language and culture have a future, it should be easy for Russians to merge into the Estonian society if they know the language, and it should be acknowledged that the Soviet Union was the occupier of Eastern Europe in the Second World War. These results demonstrate that there exists a propensity towards assimilation supported by overwhelmingly primordialist Estonian ethno-national culture backed with the Soviet Union as a negative agency from the history, while situationalist integration perspective is more considered like a challenge towards mutually respected diversity.

In order to test the hypothesis in regard to Estonia's Russians, the following comparison of the values and beliefs of ten Estonia's Russian primordialists 
(strongly so) with twelve 'situationalists' (weakly so) will be presented in Tables 6 and 7. Identity parameters (emotional significance and structural pressure) reported in the Ipseus analysis have been provided in the tables where the first three constructs as indicative in regard to propensities towards classification as 'primordialists' or 'situationalists' have been grouped on the top, thereafter all other constructs are analysed in order to distinguish between these two orientations. Polarity differences in endorsement of beliefs (dimensions of identity) demonstrate that 'situationalists' by and large have greater faith in personal autonomy than primordialists.

Whereas Estonia's Russian primordialists endorse the belief (conflicted) that the Estonian language and culture are destined to vanish in a globalising world, their 'situationalist' counterparts endorse their having a future (a secondary dimension); primordialists endorse the belief (secondary) that socio-economic position is not a factor in their command of the Estonian language, whereas 'situationalists' tend to relate language skills and citizenship with a better socio-economic status (conflicted); primordialists veer towards the belief that control and penalties are the factors that induce learning the Estonian language (conflicted), while 'situationalists' do not believe that they are so necessary (conflicted); while primordialists tend to believe that the current government is responsible for leading Estonia out of its economic crisis (conflicted), 'situationalists' tend towards a different viewpoint (conflicted); and primordialists tend to view that the experience of the post-Soviet transition assists in managing the current crisis (conflicted), while 'situationalists' subscribe more to the view that the transition experience has no relevance to managing the crisis (conflicted).

Russian primordialists endorse the belief that the Soviet Union at the time of the Second World War was the liberator of Eastern Europe (secondary dimension), whereas their 'situationalist' counterparts are conflicted over this belief. 'Situationalists' are more positively inclined towards Estonia in respect to their feeling more in common with Estonians, thinking that the Estonian society is not ethnically cleavaged and that they can merge into the Estonian society by using Estonian language (all secondary dimensions for 'situationalists', but conflicted for primordialists).

Finally, Russian 'situationalists' who have tolerance towards other people and views as a core dimension of their identity, compared with this being only a secondary dimension for primordialists. 


\section{Discussion and conclusions}

\subsection{Evidence of cleavage between primordialist and 'situationalist' Estonians}

\subsubsection{Differences in values and beliefs}

The polarities and structural pressures - core and conflicted-, which relate to the issues of the Second World War, Estonian language, out-group acceptance, recovering the economic crisis and tolerance will be discussed below (see Tables $4 \& 5)$.

The results indicate that Estonian primordialists and 'situationalists' have both shared and non-shared values and beliefs. The list of shared cores consists of 'Soviet Union as occupier in the Second World War' (PRIM: 73.55; SIT: 74.60), 'Estonian language and culture have a future' (69.46; 72.63), 'easy for Russians to merge into the Estonian society if they know the language' $(76.91 ; 74.79)$ and 'tolerance towards other people and views'. These as the core discourses of the Estonians' identity structure which are not easy to be changed even if there is a push from outside or inside of the community. It is evident that the Estonian language has the most important role for Estonians, the interpretation of the Second World War outcomes as negative for Estonia is consistent with language-related cores. Tolerance as a civic value demonstrates the openness of all Estonians towards other people although in terms of structural pressure has substantially lower value among primordialists compared to 'situationalists' (59.04 cf. 69.85).

Other differences between Estonian primordialists and 'situationalists' are experienced by favouring opposite polarities of conflicted dimensions in bipolar discourses. While primordialists endorse the belief that 'only the current government can lead Estonia out of the economic crisis', 'situationalists' support the understanding that 'recovering from the crisis does not depend on the particular government.' Conflicted discourses are subject to change within one's identity structure. Primordialists' trust in the current government to resolve the crisis (although conflicted) could be expected as this is consistent with primordialists' overall adoration of salient political groupings (as was also evident in the highest identification with the government in Table 3). Also, primordialists endorse the statement that 'wealthier and more successful non-Estonians have gained, along with better socio-economical position, both language skills and citizenship' while 'situationalists' rather express that nonEstonians' command of the Estonian language and citizenship status do not relate to their socio-economic position'. This is related to 'situationalists' propensity towards increased individual autonomy, but at large both of these differences 
regarding Estonian primordialists and 'situationalists' remain rather decent, as the dominant core dimensions refer to primordialism as the main orientation within Estonians' ethno-national identity. Situationalism among Estonians is weakly expressed. Therefore, cleavages in values and beliefs concerning Estonian ethno-national identity, when divided by their orientations in respect of primordialism and situationalism, almost do not exist.

\subsubsection{Differences in identification patterns}

Differences in identification patterns demonstrate how individuals relate to societal groupings of relevance in contemporary Estonia. The results show that compared to 'situationalists', Estonian primordialists empathetically identify more strongly with the government (see Table 3). This was also confirmed by the prevailing discourse polarity stating that 'this particular government is the one who is able to steer Estonia out of the economic crisis.' The opposition's role is less notable among primordialists and 'situationalists'. The justification here could be long-lasting governance of Reform Party and Pro-Patria coalition accompanied by 'nation-liberal ideology' accepted among primordialists and 'situationalists' as the latter category shares mostly the same values within ethnonational identity discourses. Concerning identifications with ethno-national winners-losers groups both groups empathetically identify with 'Estonians winners', (PRIM: 0.85 SIT: 0.73) but 'situationalists' lag behind. There exist no more significant differences in regard of identifications with any other ethno-national group among Estonians. This finding also contributes to earlier studies which claim that Estonians are much more consolidated compared to the country's migrant minorities, which have remained remarkably fragmented, both socially and politically, throughout the post-independence period (Vetik \& Helemäe, 2011, p. 16). 
Table 4. Structural pressure of Estonian primordialists [data in this Table indicates that overall these 11 cases are distinctly primordialist]

\begin{tabular}{|c|c|c|c|}
\hline Favoured polarity & Unfavoured polarity & $\begin{array}{l}\text { Emotional } \\
\text { significance }\end{array}$ & $\begin{array}{l}\text { Structural } \\
\text { pressure }\end{array}$ \\
\hline $\begin{array}{l}\text { Considers nationality is } \\
\text { given forever }(P)\end{array}$ & $\begin{array}{l}\text { A person is able to adapt to } \\
\text { any nationality (S) }\end{array}$ & 7.37 high & $\begin{array}{l}30.28 \\
\text { secondary }\end{array}$ \\
\hline $\begin{array}{l}\text { Language is an essential } \\
\text { hallmark of ethnic and } \\
\text { national heritage }(P)\end{array}$ & $\begin{array}{l}\text { Language is not necessary for } \\
\text { national belonging (S) }\end{array}$ & 8.34 high & $\begin{array}{l}57.58 \\
\text { core }\end{array}$ \\
\hline $\begin{array}{l}\text { National ties override } \\
\text { divisions of wealth }(P)\end{array}$ & $\begin{array}{l}\text { Economic interests rather than } \\
\text { national unite people }(S)\end{array}$ & 6.36 high & $\begin{array}{l}14.56 \\
\text { conflicted }\end{array}$ \\
\hline $\begin{array}{l}\text { Believes that only current } \\
\text { govt. can lead Estonia out of } \\
\text { the economic crisis }\end{array}$ & $\begin{array}{l}\text { Recovering from the crisis does } \\
\text { not depend on the particular } \\
\text { govt. Estonia has today }\end{array}$ & 7.33 high & $\begin{array}{l}22.47 \\
\text { conflicted }\end{array}$ \\
\hline $\begin{array}{l}\text { Wealthier and more } \\
\text { successful non-Estonians } \\
\text { have gained, along with } \\
\text { better socio-econ. pos., both } \\
\text { language skills and citizens. }\end{array}$ & $\begin{array}{l}\text { non-Estonians' command } \\
\text { of Estonian language and } \\
\text { citizenship does not relate to } \\
\text { their socio-economical position }\end{array}$ & 6.57 high & $\begin{array}{c}1.92 \\
\text { conflicted }\end{array}$ \\
\hline $\begin{array}{l}\text { Estonian society is not } \\
\text { ethnically cleavaged }\end{array}$ & $\begin{array}{l}\text { Estonian society is ethnically } \\
\text { cleavaged }\end{array}$ & 7.15 high & $\begin{array}{l}33.32 \\
\text { secondary }\end{array}$ \\
\hline $\begin{array}{l}\text { Estonian Russians feel more } \\
\text { common to Estonia }\end{array}$ & $\begin{array}{l}\text { Estonian Russians feel more } \\
\text { common to Russia }\end{array}$ & 6.85 high & $\begin{array}{l}22.24 \\
\text { conflicted }\end{array}$ \\
\hline $\begin{array}{l}\text { Estonian language and culture } \\
\text { have a future }\end{array}$ & $\begin{array}{l}\text { Estonian language and culture } \\
\text { are destined to vanish in the } \\
\text { globalising world }\end{array}$ & 8.30 high & $\begin{array}{l}69.46 \\
\text { core }\end{array}$ \\
\hline $\begin{array}{l}\text { Easy for Russians to merge } \\
\text { into Estonian society when } \\
\text { knowing the language }\end{array}$ & $\begin{array}{l}\text { It is difficult even with a } \\
\text { full command of Estonian } \\
\text { language }\end{array}$ & 8.57 high & $\begin{array}{l}76.91 \\
\text { core }\end{array}$ \\
\hline $\begin{array}{l}\text { Control and penalties } \\
\text { necessary to improve Estonian } \\
\text { language learning }\end{array}$ & $\begin{array}{l}\text { Control and penalties do not } \\
\text { result in faster integration and } \\
\text { lang. learning }\end{array}$ & 7.92 high & $\begin{array}{l}49.05 \\
\text { secondary }\end{array}$ \\
\hline $\begin{array}{l}\text { Difficulties Estonia passed after } \\
\text { transition shock have helped to } \\
\text { manage the current crisis }\end{array}$ & $\begin{array}{l}\text { Managing the current crisis } \\
\text { does not depend on the } \\
\text { experience of having survived } \\
\text { post-Soviet transition }\end{array}$ & 7.34 high & $\begin{array}{l}29.96 \\
\text { conflicted }\end{array}$ \\
\hline $\begin{array}{l}\text { Soviet Union - occupier of } \\
\text { Eastern Europe in WWII }\end{array}$ & $\begin{array}{l}\text { Soviet Union - liberator of } \\
\text { Eastern Europe in WWII }\end{array}$ & 8.79 high & $\begin{array}{l}73.55 \\
\text { core }\end{array}$ \\
\hline $\begin{array}{l}\text { Tolerant towards other people } \\
\text { and views }\end{array}$ & $\begin{array}{l}\text { Do/es not accept other people } \\
\text { and views }\end{array}$ & 7.38 high & $\begin{array}{l}59.04 \\
\text { core }\end{array}$ \\
\hline $\begin{array}{l}\text { Has a good sense of ethics and } \\
\text { social responsibility }\end{array}$ & $\begin{array}{l}\text { Is prone to corruption and self- } \\
\text { aggrandisement }\end{array}$ & 7.46 high & $\begin{array}{l}43.35 \\
\text { secondary }\end{array}$ \\
\hline
\end{tabular}


Table 5. Structural pressure of Estonian 'situationalists'

[data in this Table indicates that overall these 12 cases are very weakly situationalist with obtruding primordialist sentiment]

\begin{tabular}{|c|c|c|c|}
\hline Favoured polarity & Unfavoured polarity & $\begin{array}{l}\text { Emotional } \\
\text { significance }\end{array}$ & $\begin{array}{l}\text { Structural } \\
\text { pressure }\end{array}$ \\
\hline $\begin{array}{l}\text { A person is able to adapt to } \\
\text { any nationality (S) }\end{array}$ & $\begin{array}{l}\text { Considers nationality is given } \\
\text { forever }(P)\end{array}$ & 6.75 high & $\begin{array}{l}30.22 \\
\text { secondary }\end{array}$ \\
\hline $\begin{array}{l}\text { Language is an essential } \\
\text { hallmark of ethnic and national } \\
\text { heritage }(P)\end{array}$ & $\begin{array}{l}\text { Language is not necessary for } \\
\text { national belonging }(\mathrm{S})\end{array}$ & 7.31 high & $\begin{array}{l}29.43 \\
\text { secondary }\end{array}$ \\
\hline $\begin{array}{l}\text { National ties override divisions } \\
\text { of wealth }(P)\end{array}$ & $\begin{array}{l}\text { Economic interests rather than } \\
\text { national ones unite people }(S)\end{array}$ & 7.09 high & $\begin{array}{l}15.18 \\
\text { conflicted }\end{array}$ \\
\hline $\begin{array}{l}\text { Recovering from the crisis } \\
\text { does not depend on the } \\
\text { particular govt. Estonia has } \\
\text { today }\end{array}$ & $\begin{array}{l}\text { Believes that only the current } \\
\text { govt. can lead Estonia out of } \\
\text { the economic crisis }\end{array}$ & 6.67 high & $\begin{array}{l}-8.74 \\
\text { conflicted }\end{array}$ \\
\hline $\begin{array}{l}\text { non-Estonians' command } \\
\text { of Estonian language and } \\
\text { citizenship does not relate } \\
\text { to their socio-economical } \\
\text { position }\end{array}$ & $\begin{array}{l}\text { Wealthier and more } \\
\text { successful non-Estonians } \\
\text { have gained, along with better } \\
\text { socio-economical position, } \\
\text { both language skills and } \\
\text { citizenship }\end{array}$ & 7.42 high & $\begin{array}{c}-1.93 \\
\text { conflicted }\end{array}$ \\
\hline $\begin{array}{l}\text { Estonian society is not } \\
\text { ethnically cleavaged }\end{array}$ & $\begin{array}{l}\text { Estonian society is ethnically } \\
\text { cleavaged }\end{array}$ & 6.30 high & $\begin{array}{l}\mathbf{5 2 . 1 9} \\
\text { secondary }\end{array}$ \\
\hline $\begin{array}{l}\text { Estonia's Russians feel more } \\
\text { common to Estonia }\end{array}$ & $\begin{array}{l}\text { Estonia's Russians feel more } \\
\text { common to Russia }\end{array}$ & 6.83 high & $\begin{array}{l}26.76 \\
\text { conflicted }\end{array}$ \\
\hline $\begin{array}{l}\text { Estonian language and culture } \\
\text { have a future }\end{array}$ & $\begin{array}{l}\text { Estonian language and culture } \\
\text { are destined to vanish in the } \\
\text { globalising world }\end{array}$ & 8.02 high & $\begin{array}{l}72.63 \\
\text { core }\end{array}$ \\
\hline $\begin{array}{l}\text { Easy for Russians to merge } \\
\text { into Estonian society when } \\
\text { knowing the language }\end{array}$ & $\begin{array}{l}\text { It is difficult even with a } \\
\text { full command of Estonian } \\
\text { language }\end{array}$ & 8.31 high & $\begin{array}{l}74.79 \\
\text { core }\end{array}$ \\
\hline $\begin{array}{l}\text { Control and penalties } \\
\text { necessary to improve Estonian } \\
\text { language learning }\end{array}$ & $\begin{array}{l}\text { Control and penalties do not } \\
\text { result in faster integration and } \\
\text { lang. learning }\end{array}$ & 7.24 high & $\begin{array}{l}48.37 \\
\text { secondary }\end{array}$ \\
\hline $\begin{array}{l}\text { Difficulties Estonia passed after } \\
\text { transition shock have helped to } \\
\text { manage the current crisis }\end{array}$ & $\begin{array}{l}\text { Managing the current crisis } \\
\text { does not depend on the } \\
\text { experience of having survived } \\
\text { post-Soviet transition }\end{array}$ & 6.74 high & $\begin{array}{l}28.24 \\
\text { conflicted }\end{array}$ \\
\hline $\begin{array}{l}\text { Soviet Union - occupier of } \\
\text { Eastern Europe in WWII }\end{array}$ & $\begin{array}{l}\text { Soviet Union - liberator of } \\
\text { Eastern Europe in WWII }\end{array}$ & 8.95 high & $\begin{array}{l}74.60 \\
\text { core }\end{array}$ \\
\hline $\begin{array}{l}\text { Tolerant towards other people } \\
\text { and views }\end{array}$ & $\begin{array}{l}\text { Do/es not accept other people } \\
\text { and views }\end{array}$ & 7.78 high & $\begin{array}{l}69.85 \\
\text { core }\end{array}$ \\
\hline $\begin{array}{l}\text { Has a good sense of ethics and } \\
\text { social responsibility }\end{array}$ & $\begin{array}{l}\text { Is prone to corruption and self- } \\
\text { aggrandisement }\end{array}$ & 7.14 high & $\begin{array}{l}50.37 \\
\text { secondary }\end{array}$ \\
\hline
\end{tabular}


Table 6. Structural pressure of Russian primordialists

[data in this Table indicates that overall these 10 cases are strongly primordialist]

\begin{tabular}{|c|c|c|c|}
\hline Favoured polarity & Unfavoured polarity & $\begin{array}{l}\text { Emotional } \\
\text { significance }\end{array}$ & \begin{tabular}{|l|}
$\begin{array}{l}\text { Structural } \\
\text { pressure }\end{array}$ \\
\end{tabular} \\
\hline $\begin{array}{l}\text { Considers nationality is } \\
\text { given forever }(P)\end{array}$ & $\begin{array}{l}\text { A person is able to adapt to } \\
\text { any nationality (S) }\end{array}$ & 8.91 high & 52.00 core \\
\hline $\begin{array}{l}\text { Language is an essential } \\
\text { hallmark of ethnic and } \\
\text { national heritage }(P)\end{array}$ & $\begin{array}{l}\text { Language is not necessary for } \\
\text { national belonging }(\mathrm{S})\end{array}$ & 9.05 high & 60.52 core \\
\hline $\begin{array}{l}\text { National ties override } \\
\text { divisions of wealth }(P)\end{array}$ & $\begin{array}{l}\text { Economic interests rather than } \\
\text { national ones unite people (S) }\end{array}$ & 8.28 high & $\begin{array}{l}24.09 \\
\text { secondary }\end{array}$ \\
\hline $\begin{array}{l}\text { Estonia's Russians feel more } \\
\text { common to Estonia }\end{array}$ & $\begin{array}{l}\text { Estonia's Russians feel more } \\
\text { common to Russia }\end{array}$ & 7.70 high & $\begin{array}{l}10.74 \\
\text { conflicted }\end{array}$ \\
\hline $\begin{array}{l}\text { Soviet Union - liberator of } \\
\text { Eastern Europe in WWII }\end{array}$ & $\begin{array}{l}\text { Soviet Union - occupier of } \\
\text { Eastern Europe in WWII }\end{array}$ & 8.20 high & $\begin{array}{l}42.48 \\
\text { secondary }\end{array}$ \\
\hline $\begin{array}{l}\text { Estonian society is not } \\
\text { ethnically cleavaged }\end{array}$ & $\begin{array}{l}\text { Estonian society is ethnically } \\
\text { cleavaged }\end{array}$ & 7.31 high & $\begin{array}{l}-9.74 \\
\text { conflicted }\end{array}$ \\
\hline $\begin{array}{l}\text { Easy for Russians to merge } \\
\text { into Estonian society when } \\
\text { knowing the language }\end{array}$ & $\begin{array}{l}\text { It is difficult even with a } \\
\text { full command of Estonian } \\
\text { language }\end{array}$ & 7.87 high & $\begin{array}{l}3.75 \\
\text { conflicted }\end{array}$ \\
\hline $\begin{array}{l}\text { Estonian language and } \\
\text { culture are destined to } \\
\text { vanish in the globalising } \\
\text { world }\end{array}$ & $\begin{array}{l}\text { Estonian language and culture } \\
\text { have a future }\end{array}$ & 7.39 high & $\begin{array}{c}1.88 \\
\text { conflicted }\end{array}$ \\
\hline $\begin{array}{l}\text { non-Estonians' command } \\
\text { of Estonian language and } \\
\text { citizenship does not relate } \\
\text { to their socio-economical } \\
\text { position }\end{array}$ & $\begin{array}{l}\text { Wealthier and more } \\
\text { successful non-Estonians } \\
\text { have gained, along with better } \\
\text { socio-economical position, } \\
\text { both language skills and } \\
\text { citizenship }\end{array}$ & 7.59 high & $\begin{array}{l}24.89 \\
\text { secondary }\end{array}$ \\
\hline $\begin{array}{l}\text { Control and penalties } \\
\text { necessary to improve } \\
\text { Estonian language learning }\end{array}$ & $\begin{array}{l}\text { Control and penalties do not } \\
\text { result faster integration and } \\
\text { lang. learning }\end{array}$ & 8.54 high & \begin{tabular}{|l|}
-22.42 \\
contradictory
\end{tabular} \\
\hline $\begin{array}{l}\text { Believes that only current } \\
\text { govt. can lead Estonia out of } \\
\text { the economic crisis }\end{array}$ & $\begin{array}{l}\text { Recovering from the crisis } \\
\text { does not depend on the } \\
\text { particular govt. Estonia has } \\
\text { today }\end{array}$ & 6.91 high & $\begin{array}{l}-5.35 \\
\text { conflicted }\end{array}$ \\
\hline $\begin{array}{l}\text { Difficulties Estonia passed } \\
\text { after transition shock have } \\
\text { helped to manage with the } \\
\text { current crisis }\end{array}$ & $\begin{array}{l}\text { Managing the current crisis } \\
\text { does not depend on the } \\
\text { experience of having survived } \\
\text { post-Soviet transition }\end{array}$ & 6.89 high & $\begin{array}{l}0.30 \\
\text { conflicted }\end{array}$ \\
\hline $\begin{array}{l}\text { Tolerant towards other people } \\
\text { and views }\end{array}$ & $\begin{array}{l}\text { Do/es not accept other people } \\
\text { and views }\end{array}$ & 6.61 high & $\begin{array}{l}37.93 \\
\text { secondary }\end{array}$ \\
\hline $\begin{array}{l}\text { Has a good sense of ethics and } \\
\text { social responsibility }\end{array}$ & $\begin{array}{l}\text { Is prone to corruption and } \\
\text { self-aggrandisement }\end{array}$ & 7.68 high & \begin{tabular}{|l}
41.19 \\
secondary
\end{tabular} \\
\hline
\end{tabular}


Table 7. Structural pressure of Russian 'situationalists'

[data in this Table indicates that overall these 12 cases are weakly or conflicted situationalist]

\begin{tabular}{|c|c|c|c|}
\hline Favoured polarity & Unfavoured polarity & \begin{tabular}{|l|} 
Emotional \\
significance \\
\end{tabular} & $\begin{array}{l}\text { Structural } \\
\text { pressure }\end{array}$ \\
\hline $\begin{array}{l}\text { A person is able to adapt to } \\
\text { any nationality (S) }\end{array}$ & $\begin{array}{l}\text { Considers nationality is given } \\
\text { forever }(P)\end{array}$ & 7.56 high & $\begin{array}{l}41.09 \\
\text { secondary }\end{array}$ \\
\hline $\begin{array}{l}\text { Language is not necessary } \\
\text { for national belonging (S) }\end{array}$ & $\begin{array}{l}\text { Language is an essential } \\
\text { hallmark of ethnic and national } \\
\text { heritage }(P)\end{array}$ & 8.04 high & $\begin{array}{l}6.84 \\
\text { conflicted }\end{array}$ \\
\hline $\begin{array}{l}\text { Economic interests rather } \\
\text { than national ones unite } \\
\text { people (S) }\end{array}$ & $\begin{array}{l}\text { National ties override divisions } \\
\text { of wealth }(P)\end{array}$ & 7.18 high & $\begin{array}{l}11.12 \\
\text { conflicted }\end{array}$ \\
\hline $\begin{array}{l}\text { Estonia's Russians feel more } \\
\text { common to Estonia }\end{array}$ & $\begin{array}{l}\text { Estonia's Russians feel more } \\
\text { common to Russia }\end{array}$ & 7.48 high & $\begin{array}{l}32.37 \\
\text { secondary }\end{array}$ \\
\hline $\begin{array}{l}\text { Soviet Union - liberator of } \\
\text { Eastern Europe in WWII }\end{array}$ & $\begin{array}{l}\text { Soviet Union - occupier of } \\
\text { Eastern Europe in WWII }\end{array}$ & 8.55 high & \begin{tabular}{|l|}
17.72 \\
conflicted
\end{tabular} \\
\hline $\begin{array}{l}\text { Estonian society is not } \\
\text { ethnically cleavaged }\end{array}$ & $\begin{array}{l}\text { Estonian society is ethnically } \\
\text { cleavaged }\end{array}$ & 6.72 high & $\begin{array}{l}21.23 \\
\text { secondary }\end{array}$ \\
\hline $\begin{array}{l}\text { Easy for Russians to merge into } \\
\text { Estonian society when knowing } \\
\text { the language }\end{array}$ & $\begin{array}{l}\text { It is difficult even with a } \\
\text { full command of Estonian } \\
\text { language }\end{array}$ & 8.09 high & $\begin{array}{l}38.73 \\
\text { secondary }\end{array}$ \\
\hline $\begin{array}{l}\text { Estonian language and } \\
\text { culture have a future }\end{array}$ & $\begin{array}{l}\text { Estonian language and culture } \\
\text { are destined to vanish in the } \\
\text { globalising world }\end{array}$ & 7.64 high & $\begin{array}{l}20.60 \\
\text { secondary }\end{array}$ \\
\hline $\begin{array}{l}\text { Wealthier and more } \\
\text { successful non-Estonians } \\
\text { have gained, along with } \\
\text { better socio-economical } \\
\text { position, both language skills } \\
\text { and citizenship }\end{array}$ & $\begin{array}{l}\text { non-Estonians' command } \\
\text { of Estonian language and } \\
\text { citizenship does not relate to } \\
\text { their socio-economical position }\end{array}$ & 6.85 high & $\begin{array}{l}7.41 \\
\text { conflicted }\end{array}$ \\
\hline $\begin{array}{l}\text { Control and penalties do not } \\
\text { result faster integration and } \\
\text { lang. learning }\end{array}$ & $\begin{array}{l}\text { Control and penalties } \\
\text { necessary to improve Estonian } \\
\text { language learning }\end{array}$ & 8.38 high & $\begin{array}{l}7.78 \\
\text { conflicted }\end{array}$ \\
\hline $\begin{array}{l}\text { Recovering from the crisis } \\
\text { does not depend on the } \\
\text { particular govt. Estonia has } \\
\text { today }\end{array}$ & $\begin{array}{l}\text { Believes that only current govt. } \\
\text { can lead Estonia out of the } \\
\text { economic crisis }\end{array}$ & 7.85 high & $\begin{array}{l}12.36 \\
\text { conflicted }\end{array}$ \\
\hline $\begin{array}{l}\text { Managing the current } \\
\text { crisis does not depend on } \\
\text { the experience of having } \\
\text { survived post-Soviet } \\
\text { transition } \\
\end{array}$ & $\begin{array}{l}\text { Difficulties Estonia passed } \\
\text { after transition shock have } \\
\text { helped to manage with the } \\
\text { current crisis }\end{array}$ & 7.43 high & $\begin{array}{l}16.48 \\
\text { conflicted }\end{array}$ \\
\hline $\begin{array}{l}\text { Tolerant towards other people } \\
\text { and views }\end{array}$ & $\begin{array}{l}\text { Do/es not accept other people } \\
\text { and views }\end{array}$ & 7.35 high & 52.85 core \\
\hline $\begin{array}{l}\text { Has a good sense of ethics and } \\
\text { social responsibility }\end{array}$ & $\begin{array}{l}\text { Is prone to corruption and self- } \\
\text { aggrandisement }\end{array}$ & 6.79 high & $\begin{array}{l}37.41 \\
\text { secondary }\end{array}$ \\
\hline
\end{tabular}




\subsection{Evidence of cleavage between primordialist and 'situationalist' Russians in Estonia}

\subsubsection{Differences in values and beliefs}

For Russian primordialists there exist only two core dimensions in their ethnonational identity structure: 'considers nationality is given forever' (Structural Pressure (SP): 52.00) and 'language is an essential hallmark of ethnic and national heritage' (SP: 60.52) while for Russian 'situationalists' there exists only one core 'tolerance towards other people and views' (SP: 52.85). All the rest of the bipolar discourses have either secondary or conflicted structural pressure. Tables 6 and 7 present the lists of the constructs. It is important to notice that that 'control and penalties are necessary to improve Estonian language learning' (SP: -22.42) is extremely conflicted dimension for Russian primordialists that has even been labelled as contradictory. This is the dimension where primordialists feel the pressure from Estonian side while in their evaluations it is very stressful for them to support it when they don't have their internal acceptance to such policies. 'Situationalist' Russians endorse the opposite polarity of the same construct 'control and penalties do not result faster integration and language learning' (SP: 7.78). This difference is also affirmed by another polarisation between primordialists and 'situationalists' where primordialists endorse 'Estonian language and culture are destined to vanish in globalising world' (SP: 1.88) while 'situationalists' say 'Estonian language and culture have a future' (SP: 20.60). In regard of the economic crisis primordialists express conflicted attitude 'only the current government can steer Estonia out of the crisis', while 'situationalists' acknowledge that this does not depend on this particular government. At large, most of the bipolar identity dimensions (constructs) used for evaluation by primordialists and 'situationalists' were from different polarities. The same polarities were used only in 6 constructs out of the 14 in the case of Russians. This indicates a major distinction among Russian respondents here. Primordialists strongly express themselves by using identity dimensions which show their depression and resentment in regard to the Estonian language and culture. The Soviet Union as liberator in the Second World War continues to exist as a secondary dimension of their identity (SP: 42.48) while for 'situationalists' the same polarity of construct forms a conflicted dimension of their identity. 


\subsubsection{Differences in identification patterns}

Polarisation among Russians is strongly visible also in their identification patterns with ethno-national groups. Primordialist Russians identify more closely and empathetically with 'Estonia's Russians - losers' and thereafter their next identification pattern 'Russians in Russia'. 'Situationalist' Russians identify with 'Estonia's Russians - winners' (see Table 2). Russian 'situationalists' empathetic identification with the government and opposition are higher compared to primordialists. This can be explained also by the primordialists' deprivation and resentment reporting minimal political interest and activity.

\subsection{Conclusions}

When using primordialism and situationalism as independent variables in this quasi-experimental research design in order to establish the socio-psychological underpinnings of the ethno-national identities of Estonians and Russians, some very interesting findings were revealed.

Although the sample size is small (and data from a representative sample are required for confirmation), evidence of this research shows that the Estonian society is predominantly primordialist. This is in part revealed by the paucity of Estonian subjects who held to a situationalist perspective on ethno-national identity in this study, so that Estonian 'situationalists' actually retained elements of primordialist sentiment. The distinction between the Estonian primordialist and 'situationalist' groups is rather small. Also, the analysis shows that Estonians-winners are those with whom both primordialists and 'situationalists' have primary empathetic identification, while Estonian winners are perceived as having primordialist attributes.

Nevertheless, even given the small development towards a situationalist perspective on the part of the Estonian 'situationalists', there emerged differences so that the latters' trust in the government slightly decreases, and their identification with the government is lower. Both Estonian primordialists and 'situationalists' share the same core identity dimensions concerned with the Estonian language and culture having a future, the Soviet Union's role in the Second World War as the occupier, it being easy for Russians to merge into the Estonian society if they know the language, and having tolerance about other people and views. This set of core dimensions of identity is in essence one of assimilation towards the generally primordialist Estonian ethno-national culture with the Soviet Union cast as the evil agency of the past, rather than a situationalist integration perspective of continuing cultural heritages that 
are mutually respected for their diversity. On the other hand-the presence of 'tolerance' among these core dimensions will give some grounds to hope for acceptance for everybody, this being more true of the 'situationalists' rather than the primordialist Estonians.

In terms of Russians there is a substantial difference between Russian primordialists and 'situationalists'. This is the area where distinctions between winners and losers apply. Because of their resentment about Estonian national policies, Russian primordialists tend to identify themselves first with 'Estonia's Russians - losers' and thereafter with Russians in Russia. At the same time they hold on to the view that the Estonian language and culture are destined to vanish in globalising world, and the belief that the Soviet Union was a liberator in the Second World War.

Russian 'situationalists' tend to identify themselves first and foremost with 'Estonia's Russians - winners'. Their only core dimension of identity is related to 'tolerance about other people and views'. Features of their identity development from the past to current self reveal the most positive changes of all the Estonian and Russian groupings. Identifications with the Estonian government, Estonians-winners and even Estonians-losers have increased during the past four years according to the respondents' assessments. The question in regard to these Russian 'situationalists' and their increasing proximity to Estonian norms is whether they are going to accept the existing societal primordialism (thereby becoming assimilated) or will they be able to show the way towards the mutual acceptance of diverse ethnic heritages.

While the dimension of 'tolerance' features in all the four groupings, it is more characteristic of the 'situationalists' than the primordialists, and is only a secondary dimension for the Russian primordialists. Implacable (Estonian) language issues predominate both in the Estonian primordialist and 'situationalist' identities, as does the view of the Soviet Union being the occupier of Eastern Europe in the Second World War. For Russian primordialists the only core dimensions are the ones of nationality and ethnic language (Russian). For Russian 'situationalists', apart from the feature of 'tolerance', all of the assessed dimensions of identity are conflicted, indicating identities under considerable stress. These findings illustrate the socio-psychological nature of the dilemmas confronting the Estonian society from both Estonian and Estonia's Russian viewpoints in which the developmental psychological tenacity of primordialist sentiment predominates over situationalist perspectives. 'Tolerance' under these circumstances provides a route towards dealing with these dilemmas, even though the identity propensities revealed in the study warn about the nature of conflicts over identity cleavages within the Estonia's Russians (primordialists 
and 'situationalists') and between the Estonians (holding more to primordialism) and Russians of contrasting propensities (primordialist towards Russia; 'situationalists' towards Estonia).

Besides ethno-national identity development and mutual group acceptance, tolerance at large has been considered a substantial feature for indirectly routing the society towards economic prosperity while "seamlessly" attracting the creative class (Florida, 2003; 2009) and facilitating expression of creativity in general. The presence of the three T's (tolerance, technology, talent) will lead to the concentration of the creative class thereby creating favourable conditions for research and development. It would be most worthwhile to undertake a new ISA study focusing on these aspects related to tolerance and carried out among different segments of population (e.g., entrepreneurs, students, designers) while using the current knowledge about ethno-national identity in order to map propensities in, say, entrepreneurial identity developments related to creativity and innovation.

\section{Acknowledgements}

The current article bases on my master's thesis defended at Tallinn University in June 2012. I would like to thank my supervisors Prof. Ellu Saar (Tallinn University) and Prof. Emeritus Peter Weinreich (University of Ulster) for their support and kind advices. 


\section{References}

Connor, W. (1978), 'A nation is a nation, is a state, is an ethnic group, is a...' Ethnic and Racial Studies, vol. 1, no. 4, pp. 377-400.

Ehala, M. (2008), 'The birth of the Russian-speaking minority in Estonia,' Eurozine, 11 September 2008. Retrieved from http://www.eurozine.com/articles/2008-0911-ehala-en.html [26 Mar 2012]

Epstein, A. L. (1978), Ethos and Identity: Three Studies in Ethnicity, London: Tavistock. Estonian Integration Monitoring 2011 (2012), Summary of Estonian Integration Monitoring. Retrieved from http://www.kul.ee/webeditor/files/integratsioon/ Integratsiooni_monitooring_2011_ENG_lyhiversioon.pdf [accessed 10 Apr 2012]

Ewart, S. \& Weinreich, P. (2006), 'Emotional significance of a construct,' ISA Definitions and Algorithms. Retrieved from http://www.identityexploration.com/ uploads/files/Emotional_significance_of_a_construct.pdf [accessed 20 Apr 2012]

Florida, R. (2009), Who's your City? How the Creative Economy Is Making Where to Live the Most Important Decision of Your Life, Toronto: Vintage Canada Edition.

— (2003), 'Cities and the Creative Class,' City \& Community, vol. 2, no. 1 (March 2003), pp. 3-19.

Geertz, C. (1963), 'The integrative revolution: Primordial sentiments and civil politics in the new states,' in C. Geertz (ed.) Old Societies and New States: The Quest for Modernity in Asia and Africa, New York: The Free Press of Glencoe, pp. 105-157.

Glazer, N. \& Moynihan, D. (1975), 'Introduction,' in N. Glazer \& D. Moynihan (eds.) Ethnicity: Theory and Experience, Cambridge, MA: Harvard University Press, pp. $1-26$.

Greely, A. M. (1974), Ethnicity in the United States: A Preliminary Reconnaissance, New York: Wiley.

Halsey, A. H. (1978), 'Ethnicity: A primordial bond?' Ethnic and Racial Studies, vol. 1, no. 1, pp. 124-128.

Hechter, M. (1974), 'The political economy of ethnic change,' American Journal of Sociology, vol. 79, no. 5, pp. 1151-1178.

Horenczyk, G. \& Munayer S. (2003), 'Complex patterns of cultural allegiances: The ethnic identity of Palestinian Christian Arab adolescents in Israel,' in P. Weinreich \& W. Saunderson (eds.) Analysing Identity: Cross-Cultural, Societal, and Clinical Contexts, London \& New York: Routledge, pp. 171-189.

Isaacs, H. R. (1975), Idols of the Tribe: Group Identity and Political Change, New York: Harper \& Row.

Kelly, A. J. D. (1989), 'Ethnic identification, association and redefinition: Muslim Pakistanis and Greek Cypriots in Britain,' in K. Liebkind (ed.), New Identities in Europe: Immigrant Ancestry and the Ethnic Identity of Youth, London: Gower, pp. $77-115$. 
Kirch, A.; Rull, E. \& Tuisk, T. (2001), 'Group identity dynamics of Estonian and Polish students in the EU integration process,' Trames, vol. 5(55/50), no, 4, pp. 321-335.

Kirch, A. \& Tuisk, T. (2008), 'Etics, emics, Estonians and Russians in contemporary Estonia: is the past still dominating the present?' in Collection of research articles dedicated to the $10^{\text {th }}$ Anniversary of the Institute for European Studies Proceedings of the Institute for European Studies, Tallinn: Institute for European Studies, International University Audentes, TSEBA, vol. 4, pp. 67-94.

Kirch, A.; Tuisk, T. \& Reinkort, H.- H. (2011), 'Estonians and Russians in Contemporary Estonia: Is the Past still Dominating the Present?' in J. Deutsch, M. Boehnke, U. Kühnen \& K. Boehnke (eds.) Rendering Borders Obsolete: Crosscultural and cultural psychology as an interdisciplinary, multi-method endeavor, Bremen: Jacobs University Bremen \& International Association for Cross-Cultural Psychology, pp. 106-119.

Laitin, D. D. (1998), Identity in Formation: The Russian-Speaking Populations in the Near Abroad, Ithaca \& London: Cornell University Press.

Lauristin, M. (2011), 'In summary: What could the Baltic way be in the 21 st century?' in Estonian Human Development Report: Baltic Way(s) of Human Development: Twenty Years On, Tallinn: Eesti Koostöö Kogu, pp.192-198.

Lauristin, M.; Uus, M. \& Seppel, K. (2012), 'Kodakondsus, kodanikuühiskond ja rahvussuhted,' in Integratsiooni monitooring 2011, Tallinn: Poliitikauuringute Keskus Praxis. Retrieved from http:/www.kul.ee/webeditor/files/integratsioon/ Integratsiooni_monitooring_2011.pdf [accessed Oct 2012]

Lindemann, K. \& Saar, E. (2011), 'Ethnic inequalities in education,' in R. Vetik \& J. Helemäe (eds.) The Russian Second Generation in Tallinn and Kohtla-Järve: The TIES Study in Estonia: IMISCOE Reports, Amsterdam: Amsterdam University Press, pp. 59-92.

Mitchell, J. C. (1974), 'Perceptions of ethnicity and ethnic behaviour: An empirical exploration,' in A. Cohen (ed.) Urban Ethnicity, London: Tavistock, pp. 1-35.

Nagata, J. (1974), 'What is a Malay? Situational selection of ethnic identity in a plural society,' American Ethnologist, vol. 1, no. 2, pp. 331-350.

Narusk, A. \& Hansson, L. (1999), Estonian Families in the 1990s: Winners and Losers, Tallinn: Institute of International and Social Studies \& Estonian Academy Publishers.

Okamura, J. Y. (1981), 'Situational ethnicity,' Ethnic and Racial Studies, vol. 4, no. 4, pp. 452-465.

Rimm, I. \& Tuisk, T. (1997), 'Identity Structure Analysis and Integration Processes,' in A. Kirch (ed.) The Integration of Non-Estonians into Estonian Society: History, Problems and Trends, Tallinn: Estonian Academy Publishers, pp. 37-47.

Ruutsoo, R. (2002), 'Discursive Conflict and Estonian Post-Communist NationBuilding,' in M. Lauristin \& M. Heidmets (eds.) The Challenge of the Russian 
Minority: Emerging Multicultural Democracy in Estonia, Tartu: Tartu University Press, pp. 31-54.

Shils, E. (1957), 'Primordial, personal, sacred and civil ties,' The British Journal of Sociology, vol. 8, no. 2, pp. 130-145.

Smith, A. D. (1981), The Ethnic Revival in the Modern World, Cambridge: Cambridge University Press.

State Programme "Integration in Estonian Society 2000-2007" (2000), Tallinn: Government of Estonia. Retrieved from http:/www.kul.ee/webeditor/files/ integratsioon/state_programme111.pdf (accessed 12 Apr 2012]

Tuisk, T. (1994), 'Methodological Aspects of Identity Structure Analysis,' in A. Kirch \& D. Laitin (eds.) Changing Identities in Estonia: Sociological Facts and Commentaries, Tallinn: Akadeemia Trükk, pp. 25-30.

Vetik, R. (2002), 'Multicultural democracy as a new model of national integration in Estonia,' in M. Lauristin \& M. Heidmets (eds.) The Challenge of the Russian Minority: Emerging Multicultural Democracy in Estonia, Tartu: Tartu University Press, pp. 55-62.

Vetik, R. \& Helemäe, J. (2011), 'Introduction,' in R. Vetik \& J. Helemäe (eds.) The Russian Second Generation in Tallinn and Kohtla-Järve: The TIES Study in Estonia: IMISCOE Reports, Amsterdam: Amsterdam University Press, pp. 13-26.

Vihalemm, T. \& Kalmus, V. (2009), 'Cultural Differentiation of the Russian Minority,' Journal of Baltic Studies, Special Issue: From Post-Communism to the EU: Estonia's Transition 20 Years On, vol. 40, no. 1, pp. 95-119.

Vihalemm, T. \& Siiner, M. (2011), 'Language and integration policies of the Baltic states in the EU context,' in Estonian Human Development Report: Baltic Way(s) of Human Development: Twenty Years On, Tallinn: Eesti Koostöö Kogu, pp. 122-129.

Vogt, H. (2011), 'Estonia - ever more firmly in the nation-liberal course?' Baltic Rim Economies, Quarterly Review, no 2, 31 May 2011. Retrieved from http://www. tse.fi/FI/yksikot/erillislaitokset/pei/Documents/BRE2011/BRE\%202-2011\%20 final\%2030.5.2011.pdf [accessed 11 Feb 2012]

Weinreich, P. (2003), 'Part I: Theory and practice,' in Analysing Identity: CrossCultural, Societal, and Clinical Contexts, London \& New York: Routledge, pp. $1-76$.

— ([1980]1986), Manual for Identity Exploration using Personal Constructs [Reprint], Coventry: University of Warwick, Economic and Social Research Council, Centre for Research in Ethnic Relations.

Weinreich, P.; Bacova, V. \& Rougier, N. (2003), 'Basic primordialism in ethnic and national identity,' in Analysing Identity: Cross-Cultural, Societal, and Clinical Contexts, London \& New York: Routledge, pp. 115-169.

Weinreich, P. \& Ewart, S. (2007), Ipseus computer software for identity exploration, Belfast: Sycadex Ltd. Retrieved from http://www.identityexploration.com 
Weinreich, P.; Luk, C. L. \& Bond, M. H. (1996), ,Ethnic stereotyping and identification in a multicultural context: "Acculturation", self-esteem and identity diffusion in Hong Kong Chinese university students,' Psychology and Developing Societies, vol. 8, no. 1, pp. 107-169.

Weinreich, P. \& Saunderson, W. (eds.) (2003), Analysing Identity: Cross-Cultural, Societal, and Clinical Contexts, London \& New York: Routledge 